\title{
Activating HRAS Mutation
}

National Cancer Institute

\section{Source}

National Cancer Institute. Activating HRAS Mutation. NCI Thesaurus. Code C139798.

A change in the nucleotide sequence of the HRAS gene that that results in constitutive activation of both oncogene $\mathrm{H}$-Ras protein and its downstream signaling pathways. 